\title{
Analyzing the role of Values, Beliefs and Attitude in Developing Sustainable Behavioral Intentions: Empirical Evidence from Electric Power Industry
}

\author{
Muhammad Danish Habib ${ }^{1}$, Hassan Jalil Shah ${ }^{2}$, Abdul Qayyum ${ }^{3}$
}

\begin{abstract}
Energy conservation is an economic, social, and environmental issue that offers various academic, practical, and policy implications. The growing magnitude, complexity, and relevance of energy wastage have attracted the attention of scholars and practitioners. This research aims to measure the effect of beliefs, values, and attitudes on sustainable behavioral intentions in the energy conservation context. This research hypothesized awareness, compatibility, perceived value, resistance to change, and actual gain as predictors of attitude towards energy conservation and sustainable behavioral intentions. Using survey methodology, purposive sampling techniques were used to collect the data from young household consumers. Data of 246 electricity consumers of Pakistan were analyzed using confirmatory factor analysis (CFA) and structural equation modeling (SEM). Findings: Results of the study validate a significant relationship between attitude towards energy conservation and sustainable behavioral intentions. Based on results, it has been established that the amount of actual gain intentions and awareness are the main contributors to attitude towards energy conservation and sustainable behavioral intention. Compatibility and resistance to change were also significant precipitators of attitude towards energy conservation and sustainable behavioral intention. Perceived value was found a significant predictor of attitude towards energy conservation while insignificant towards sustainable behavioral intention. The study findings have a significant impact on government, policymakers, marketers, and academics interested in developing strategies to mitigate the effects of energy wastage. Prevention of resource wastage depends upon the awareness and consumption practices of the customers. There is a lack of consumer awareness towards electricity conservation practices of household consumers in the context of developing countries. This research utilized the theory of planned behavior to explain sustainable behavioral intentions in the context of electricity conservation.
\end{abstract}

1 Lecturer, Department of Business Administration, Air University Islamabad, Aerospace and Aviation Campus, Kamra, Pakistan. Email: danish.habib@au.edu.pk

2 Advisor, Human Resource Development, Higher Education Commission of Pakistan, Islamabad Pakistan.

E-mail: hjsha@hec.gov.pk

3 Associate Professor, Department of Management Sciences, Riphah School of Leadership, Riphah International University, Islamabad Pakistan.E-mail: abdul.qayyum@riphah.edu.pk

\section{ARTICLE HISTORY}

07 Sep, 2020 Submission Received 29 Nov, 2020 First Review
18 Jan, 2021 Second Review
13 Feb, 2021 Accepted 
Keywords: Energy conservation, theory of planned behavior, actual gain, resistance to change, Pakistan

\section{Introduction}

The recognition of ecological and environmental issues is increasing with every passing day. The concern for the development and protection of natural resources has attracted the attention of literary and policy circles over a period of time. Both academicians and practitioners are paying greater attention to environmental issues at national and global scale (Hantrais, Kattumuri \& Lenihan, 2020; Rezvani, Jansson $\&$ Bengtsson, 2018). The veracity of the assertion can be corroborated by the fact that climate change, environmental degradation, clean water and affordable and clean energy are part of the 17 interconnected Sustainable Developmental Goals (SDG) set by the United Nations (Ahmad \& Riffat, 2020; Arora \& Mishra, 2019). Correspondingly, environmental ideology and related issues have found a preeminent place in the literature related to marketing (Rahman, Aziz \& Hughes, 2020).

Concerns for protecting the environment for future generations, preventing ecological degradation, and conserving natural resources as a part of a larger strategy to protect the environment have been proved to be positively correlated by the literature (Sun, Zhang, Li, Wu \& Zheng, 2018). It was found that environmental concern and consideration of future consequences were positively and considerably related to electricity use, hence proving the assertion of linkages between environmental concerns and energy conservation is direly needed (Bruderer Enzler, Diekmann \& Liebe, 2019).

Pakistan has witnessed energy crisis for decades (Abbasi, Abbas, Mahmood \& Tufail, 2021), which makes a very strong case for undertaking a study to determine the behavior of Pakistani citizens towards conserving energy as part of an overall paradigm to protect the environment and help the country in getting out of this challenge. It is estimated that Pakistan is facing a shortfall between 4,000-5,000 megawatt, and this shortage is impinging upon the economic growth of Pakistan (Latif, Raza, Chaudhary $\&$ Arshad, 2020). Though Pakistan has come a long way in overcoming the acute shortage of electricity demand, production of 22,000 MW against the consumers' demand of 25,000 MW leaves a deficit of 3,000 MW of electricity in Pakistan (Rehman, 2018). It was found that electricity shortfall has lowered economic growth by $2 \%$ in Pakistan (Chandio, Rauf, Jiang, Ozturk \& Ahmad, 2019). Besides this household sector is the largest electricity consumer accounted for $46 \%$ of the total electricity consumption, with 25\% of the population still lacking electricity (Biresselioglu, Demir, Rashid, Solak \& Ozyorulmaz, 2019). A survey regarding the shortfall of energy found that a waste of $25 \%$ in the household is inefficient household appliances (Ahmad, Kashif, Saqib, Ashraf \& Shami, 2019). 
The increased wastage of electricity at households arose the importance of electricity consumption behavior, which may significantly impact electricity use and its conservation to overcome its wastage (Trotta, 2021). The mounting research on consumer behavior towards energy conservation gradually improves the understanding to overcome the issue of energy shortage. However, consumer behavior is complex and challenging to predict accurately (Khan, Ahmed \& Najmi, 2019). Scholars have suggested that multiple unknown reasons can instigate electricity conservation, highlighting the need for appropriate theoretical frameworks to uncover these reasons behind such complex consumption behavior (Thøgersen, 2021; Trotta, 2021). The plethora of previous research on the subject notwithstanding, a need is still felt for further exploration into normative and psychological factors related to behavioral intentions. It is important to apprehend the impact of beliefs, values, and attitudes on behavioral intentions (Waris \& Ahmed, 2020). There lies inconsistency among their association (Fornara, Pattitoni, Mura \& Strazzera, 2016; van den Broek, Walker \& Klöckner, 2019). Whereas abundant literature on sustainable behavior is in the context of developed countries can be easily found, there is a dearth of studies investigating sustainable behavior in developing countries (Zhao \& Guo, 2014), like Pakistan facing an energy crisis (Latif et al., 2020). The current study aims to address the aforementioned gap by examining the different drivers of sustainable behavioral intentions. The Theory of Planned Behavior (TPB) is a widely used theoretical lens (Savari \& Gharechaee, 2020; Waris \& Ahmed, 2020; Yuriev, Dahmen, Paillé, Boiral, $\&$ Guillaumie, 2020). TPB adopts a cognitive approach to explore consumer behaviors (Ajzen, 2001). Consistent with the view that cognitive aspects are significantly associated with behavioral intentions (Chen, 2016). The VBN theory was established to explain the influence of values and beliefs on behavioral intentions (Gkargkavouzi, Halkos, \& Matsiori, 2019). The current study examines the role of cognitive factors in driving sustainable behavioral intentions. The study utilizes the two theoretical lenses, namely TPB and VBN, to postulates awareness, compatibility, perceived value, resistance to change, and actual gain as drivers of attitude towards energy conservation and sustainable behavioral intentions. The present study narrows down its scope to electricity conservation as one of the most important domains of sustainability, which merits particular attention and research specifically in Pakistan's context.

Additionally, the present study only considers the cognitive aspects to examine the behavioral intentions. The study results contribute to the existing body of knowledge by examining sustainable behavioral intentions. The study findings equip scholars with a better understanding of the role of cognition in engaging consumers towards electricity conservation. Practitioners and regulators can utilize the study to educate the household consumer and develop social marketing and advertisements to persuade consumers to engage in sustainable behavioral intentions. 


\section{Theoretical Framework and Hypotheses Development}

\subsection{Theoretical framework}

Research studies have identified pro-environmental behavior as an individual's behavior inspired by expected desirable consequences (Lunden, Sundstrom,\& Suliman, 2020) or social behavior (Fabi, Di Nicoli, Spigliantini \& Corgnati, 2017; Ohtomo \& Hirose, 2007). A number of viewpoints attempted to provide divergent axis to anticipate cognitive reasons for sustainable behavior (Bamberg \& Moser, 2007). For instance, the theory of planned behavior (Ajzen, 2001), the theory of norm activation (Kornilaki \& Font, 2019; Schwartz, 1977), and value-belief norm theory (VBN) (Gkargkavouzi et al., 2019). Theory of planned behavior (TPB) is a widely used theoretical lens for analyzing behavioral intentions (Tan, Ooi \& Goh, 2017). TPB postulated that cognitive aspects predict behavioral intentions (Lopes, Kalid, Rodríguez \& Ávila Filho, 2019; Yuriev et al., 2020). The VBN theory establishes values and beliefs as predictors of behavioral intentions (Gkargkavouzi et al., 2019). Some researchers argued that integrating the different perspectives is preferable since the behavior concerning the environment is not affected by the attitude variables band. The developed research model utilized two well-known theoretical lenses, namely the TPB and VBN.

\subsection{Hypotheses development}

\subsubsection{Sustainable behavioral intentions}

Ajzen (2001) argued that customers' behavioral intention represents an individual's anticipations about a specific behavior in the available scenario(Weissmann, 2020). Furthermore, Bonnes and Bonaiuto (2002) define sustainable behavior as a collection of effective and intentional activities aimed at conserving the physical-socio habitat for society at large and generations to come (Quoquab, Mohammad \& Sukari, 2019). It is also defined as the behavior that encapsulates peoples' values, norms, beliefs, senses of responsibility in a considered action which is focused on providing well-being of all living beings, including present and future generations (Sonetti, Brown \& Naboni, 2019). By considering this elucidation in the backdrop of this research, the sustainable behavior of users must incorporate such activities that are meant for the preservation of electricity and behavior that is considerate towards other individuals and groups (Corral-Verdugo, Mireles-Acosta, Tapia-Fonllem \& Fraijo-Sing, 2011; Lopes et al., 2019). It has also been asserted that one's behavior plays a significant role in creating and solving environmental issues (Heo \& Muralidharan, 2019). This is the reason that a fundamental shift in individuals' behavior can lead to a safe environment. People inclined to exhibit sustainable behavior have moderate levels of energy consumption (Malodia \& Bhatt, 2019). it has also been claimed that 
sustainable behavior is about the conservation of natural resources and taking care of other members of society (Mróz, Ocetkiewicz \& Tomaszewska, 2020).

\subsubsection{Awareness and consumer attitude toward energy conservation}

Awareness is defined as the quality or state to be aware of something (Vess, 2019). Environmental awareness is defined as the scale to which individuals are conscious about and acquainted with information about environmental problems and their applications for their solution (Liobikien】 \& Poškus, 2019; Rezvani et al., 2018). It has been proposed that individuals will demonstrate environmental friendly behavior if they are more conscious and aware of the present state of the environmental issues (Degirmenci \& Breitner, 2017; Yuriev et al., 2020). It was also argued that more consciousness about environmental awareness increases the individual's sense of ethical obligations and influences consumers' attitudes and, in turn, impact environmental behaviors (Chen \& Hung, 2016). Taking this into consideration, it can be proposed that individuals will tend to save electricity if they are more alive to the problems of electricity shortage in Pakistan (Shah \& Solangi, 2019). From the perspective of the theory of planned behavior, environmental awareness might be considered a component of the subjective norm (Nie, Vasseur, Fan \& Xu, 2019). Nguyen, Lobo and Greenland (2017) identified that awareness about environmental issues is represented by possession of relevant knowledge and identifying problems related to the environment. Based on the above-cited literature, it can be anticipated that:

Hypothesis 1: Awareness has a positive and significant impact on consumer attitude toward energy conservation.

\subsubsection{Compatibility and consumer attitude toward energy conservation}

Compatibility is a state in which two things are able to exist or occur together without problems or conflict. It is explained as a degree to which new behavior shows consistency with current practice. For instance, the sustainable behavior of an individual depicts his/her way of spending life (Ramayah \& Rahbar, 2013). Rogers (2002) interpreted compatibility as the degree to which an innovative product is in line with past experiences and present values. Chen, Gillenson, and Sherrell (2002), proposed an association between compatibility beliefs and attitude; instead, compatibility leads to perceived behavioral control. According to Mayer and Frantz (2004), individuals who have concerns about gaining health benefits and who have a high sense of belonging with nature are more expected to demonstrate eco-friendly behaviors. Thus, if there is a link between an individual tendency and his goal to sustainable behavior in his life, it can be concluded that compatibility will significantly impact sustainable products' attitude. From VBN theory, compatibility, which is acknowledged as beliefs 
Chen, Gillenson, and Sherrell (2002), precedes attitude. So it can be proposed that:

Hypothesis 2: Compatibility has a positive and significant effect on consumer attitude toward energy conservation.

\subsubsection{Perceived value and consumer attitude toward energy conservation}

Perceived value can generally be explained as assessing a person that estimates the benefits gained from product or service vis-à-vis perceived cost and sacrifices given by a customer (Konuk, 2019; Lovelock, Patterson \& Wirtz, 2014). Ajzen (2001) has described perceived value as "an individual's thoughts relating to the usefulness of anticipated precautionary behavior so that exposure to the negative consequences is reduced." It was advocated that a person's value for sustainable products is inspired by the personal assessment of the utility gained and the cost given (Parasuraman, Zeithaml \& Berry, 1985; Roos \& Hahn, 2019). Researchers asserted that customers always evaluate products according to their perception and value results from those evaluating judgments (Shi et al., 2019; Yin et al., 2019). Therefore, the importance and worth of conservation of energy sources would depend on the individual's perception. Thus, for individuals, the sustainable attitude has to be endowed with values by integrating benefits of using sustainable goods or benefits of saving the energy sources, that is, electricity (Chiu et al., 2020; Dodds, Monroe \& Grewal, 1991). Moreover, Ramayah and Rahbar (2013) and Tzeng (2011) proved the positive impact of value on attitude. From the above literature, it can be inferred that customers will save electricity because they think it encompasses value for the future, and saving electricity will benefit new generations and their countries (Khan, 2019).

Hypothesis 3: Perceived value positively and significantly contributes to consumer attitude toward energy conservation.

\subsubsection{Resistance to change and consumer attitude toward energy conservation}

Oreg (2006) argued that individuals who show resistance towards change are always reluctant to incorporate changes in their lives; hence their attitude will be negative towards particular changes they come across (Gaustad, Samuelsen, Warlop \& Fitzsimons, 2019). Therefore, people who are resistant to change have disagreements and objections to the change. It was found that some personality characteristics are related to maintaining the status quo (Wynter-Hoyte, Braden, Rodriguez \& Thornton, 2019). Similarly, Campbell (2006) also determined the linkage between individual traits and unwillingness to change, learning beliefs and interests of a person, and tendency to trust. Results showed that individuals with greater beliefs and interest in learning had more constructive attitudes, and their resistance to change was lower than other military cadets. Thus, it indicates that individuals who are less resistant to 
change would be conscious of green behavior results on their environment (Ramayah \& Rahbar, 2013; Shi et al., 2019). Beliefs about resistance to change as an attitude are conceptualized as multi-dimensional (Zehra \& Siddiqui, 2019). These dimensions are named affective, cognitive, and behavioral components (Zehra \& Siddiqui, 2019). These studies explored phenomena associated with aversion towards change with respect to an individual's standpoint (Oreg, 2006). Based on the above-cited literature, it can be hypothesized that:

Hypothesis 4: Resistance to change has a significant and negative impact on consumer attitude toward energy conservation.

\subsubsection{Perceived actual and consumer attitude toward energy conservation}

In research studies, actual gain having wider scope has not been defined specifically. However, the actual gain is described by some authors as acquiring some benefit or advantage after doing something. According to Ramayah and Rahbar (2013), the actual gain is some benefits that students can gain from the recycling process, hence leads to recycling behavior. It is presumed that consumers who are not inspired to save the environment do not have enough awareness and knowledge (Panda et al., 2020). Ramayah and Rahbar (2013) proved that individuals who obtain actual gain from recycling have a positive attitude toward saving the environment. Researchers have identified that the perception of benefits influences the attitude of consumers. There is a positive relationship between actual gain and attitude (Bredahl, 2001; Park $\&$ Kwon, 2017). So it can be proposed that:

Hypothesis 5: Perceived actual gain change positively contributes to consumer attitude toward energy conservation.

\subsubsection{Attitude towards energy conservation and sustainable behavioral intentions}

It was argued that intentions of unusual behavior are more likely to be influenced by attitude than the intent of consumers to repeat habitual behavior (Mahardika, Thomas, Ewing \& Japutra, 2020). The relationship between behavioral intention and attitude was determined weaker when the consumer behavior is habitual (Mahardika et al., 2020). It was found stronger when behavior is not habitual. In other words, it was argued that when behavior is habitual, consumers intended to do things in the same way and that behavior is not much influenced by the attitude of the consumers (Kaiser, Kibbe \& Arnold, 2017; Wang, Wang, Guo, Zhang \& Wang, 2018). On the contrary, Knussen, Yule, MacKenzie and Wells (2004) argued that the relationship between the intentions of consumers to recycle and attitude towards recycling is stronger for those who have the habit of recycling their waste than those who do not have the habit of recycling the things. Research studies also identified a 
positive relationship between beliefs and values (awareness, compatibility, perceives value, resistance to change, actual gain) and behavioral intentions (Kautish, Khare \& Sharma, 2020; Ramayah \& Rahbar, 2013). Based on the aforementioned literature, the following hypotheses can be proposed:-

Hypothesis 6: Awareness positively and significantly contributes to behavioral intentions.

Hypothesis 7: Compatibility has a positive and significant effect on behavioral intentions.

Hypothesis 8: Perceived value has a positive and significant impact on behavioral intentions.

Hypothesis 9: Resistance to change has a negative and significant impact on behavioral intentions.

Hypothesis 10: Actual gain change positively and significantly contributes towards behavioral intentions.

Hypothesis 11: Consumer attitude toward energy conservation has a significant impact on behavioral intentions.

The aforementioned theories and literature review regarding attitude and behavioral intentions allow us to draw a research framework shown in Figure 1.

\section{Methodology}

This study has utilized a cross-sectional survey design for the data collection from electricity consumers. The purposive sampling strategy uses the intercept approach with the 'age' filter as respondents' and 'country of origin' filter as Pakistan. The survey

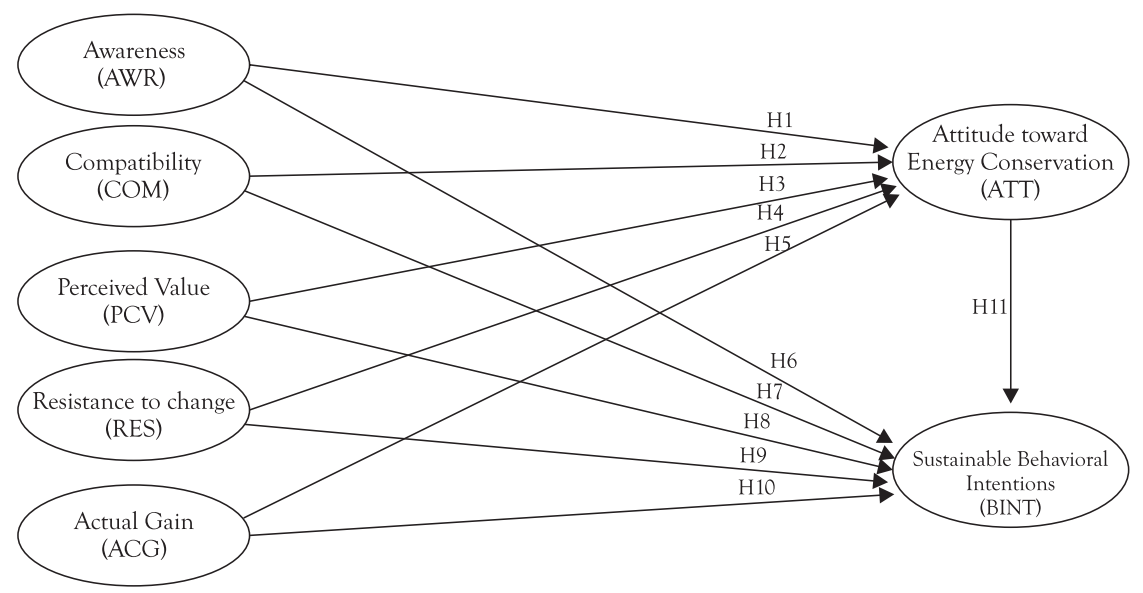

Figure 1: Research Framework 
was conducted in the first-tier metropolitan cities of Pakistan. Metropolitan cities of Pakistan bear the major proportion of the population and face immense challenges regarding socio-economic circumstances such as electricity shortfall, lack of clean water, solid waste management, and inadequate sanitation (Mangi, Yue, Kalwar \& Lashari, 2020). Young respondents were considered as more appropriate and representative for this study. First, the young generation represents a major segment of $51.25 \%$ of the Pakistani consumer market (Pakistan Bureau of Statistics, 2018). The second young generation being the future makes significant differences in shaping consumer markets and consumption patterns. Recent studies also found young consumers more appropriate and proxy of general populations in representing behaviors towards energy conservation (Islam et al., 2021; Ren et al., 2020). The respondents were requested to voluntarily participate in the research. The respondents were also addressed about confidentiality and anonymity of information before getting responses. A total of 300 questioners were distributed, 246 questionnaires were found completely filled and valid. It represented a valid return rate of 82.33 percent.

Research observers have suggested different criteria for sample size ranged between 50 to 460 cases, such as 200 responses or at least five cases per parameter estimate. From the perspective of five cases per parameter estimate, 120 responses were required for 24 items; however, a larger sample is preferable to overcome the sampling errors (Wolf, Harrington, Clark \& Miller, 2013). In the final data analysis, 246 valid responses were included. Data were analyzed with the help of Covariance based Structural Equation Modeling (SEM). Covariance-based Structural Equation Modeling is considered a more appropriate estimation tool for theory testing and confirmation of theory (Jannoo, Yap, Auchoybur \& Lazim, 2014). The sample of 246 young consumers included $54 \%$ males and 46\% females, with 34\% of respondents having age less than 22 years, $39 \%$ belonging to the age group of 23 to $27,22 \%$ between the age group of $27-32$ years, and $5 \%$ were at the age of 33 and above. The education profile of the respondents represented that $2 \%$ of the respondents were holding metric, $6 \%$ intermediate, $39 \%$ bachelor, $35 \%$ masters, and $18 \%$ above master degree. The monthly income profile of the respondents represents that the income of $30 \%$ of the respondents was less than 50000 , the earning of $40 \%$ was between the range of $50001-100000,16 \%$ were between the range of $100001-150000,9 \%$ were between the range of 150001-200000, and only 5\% were above 200000 rupees.

\subsection{Measures}

The survey questionnaire consisted of two sections. The first section was designed to record the information about respondents' gender, age, education, and income. The second section was structured to measure the study variables. Each variable consisted 
of multiple items, and respondents were asked to record their response on a 5 - point Likert scale ranged from 1 for strongly disagree to 5 for strongly agree. Awareness was measured with 3 items scale adopted from Ha and Janda (2012). Compatibility was measured with 3 item scale adopted from (Meuter, Bitner, Ostrom \& Brown, 2005). Perceived value was measured with 3 items scale adopted from (Ryu, Lee \& Gon Kim, 2012). Resistance to change was measured with 6 items scale adapted from Oreg (2006). Actual gain was measured with 3 items adapted from Ramayah and Rahbar (2013). Attitude toward energy conservation was measured with 4 items scale adapted from Ha and Janda (2012). Sustainable behavioral intentions were measured with 4 items scale adapted from (Rex, Lobo \& Leckie, 2015).

\section{Data Analysis}

The study was conducted to empirically test the proposed model for role awareness, compatibility, perceived value, resistance to change, and attitude towards sustainable behavioral intentions. Two-step structural equation modeling was used to establish the validity, reliability of data and test the proposed relational paths using AMOS 23.

\subsection{Measurement model}

Confirmatory factor analysis (CFA) was conducted to ensure convergent validity, discriminant validity, and reliability of study measures. Factor loads, Composite reliability (CR), average variance extracted (AVE), and Cronbach alpha were calculated estimated for the establishment of convergent validity, discriminant validity, and reliability of measures. Results revealed that factor load for each item $(>.5)$ except two items of resistance to change, the value of CR (>.7), the value of AVE (.5), and Cronbach alpha $(>.7)$ for each variable were above the threshold value (Fornell \& Larcker, 1981; Hair, Sarstedt, Ringle \& Mena, 2012; O’Leary-Kelly \& Vokurka, 1998). All measures fall in the acceptable level of reliability shown in Table 1. Furthermore, the square root of AVE is greater than the inter construct correlation, an indication of discriminant validity. The structural model was estimated to examine the relationship between constructs (AWR, COM, PCV, RES, ACG, ATT, and BINT). Results of descriptive statistics, Fornell-Larcker discriminant validity, and correlation analysis are presented in Table 2 .

\subsection{Structural model}

The results for the structural model (see Table 3 and Figure 2) shows that CMIN/ df (>3) was 1.707, GFI was 0.909 (>.9), AGFI was 0.891(>.85), NFI was 0.880 (>.85), CFI was $0.946(>.9)$, RMSEA was $0.044(<.08)$ which shows acceptable results. $\mathrm{H}_{1}$ 
hypothesized a positive and significant impact of AWR on ATT $(\beta=.134 ; p<0.001)$ found statistically significant. $\mathrm{H}_{2}$ proposed a positive impact of COM on ATT was also significant $(\beta=.092 ; p<0.001) . \mathrm{H}_{3}$ predicting a positive effect of PVC on ATT, was statistically significant $(\beta=.041 ; \mathrm{p}<0.001) . \mathrm{H}_{4}$, postulated a negative impact of RES on ATT was also significant $(\beta=-.235 ; p<0.001) . \mathrm{H}_{5}$, predicting the positive effect of ACG on ATT, was also statistically significant $(\beta=.136$; $p<0.001)$.

$\mathrm{H}_{6}$ hypothesized a positive impact of AWR on BINT was significant $(\beta=.100$; $p<0.001 . \mathrm{H}_{7}$ proposed a positive effect of COM on BINT was also significant $(\beta=.065$; $p<0.001) . \mathrm{H}_{8}$ predicting a positive effect of PVC on ATT, was not statistically significant $(\beta=.022 ; p>0.001)$, not in support of $\mathrm{H} 8 . \mathrm{H}_{9}$, postulated an adverse effect of RES on ATT was also significant $(\beta=-.212 ; p<0.001)$. $\mathrm{H}_{10}$, predicting the positive impact of ACG on ATT, was also statistically significant $(\beta=.116 ; p<0.001)$. ATT has a positive and significant impact on BINT significant $\left(\beta=.505 ; p<0.001\right.$, thus supporting $\mathrm{H}_{11}$. Finally, the results showed that the variance explained by the structural model was $65 \%$ for attitude towards energy conservation, $58 \%$ for sustainable behavior intentions.

\section{Discussion}

This study probed the structural relationship of energy conservation and sustainable behavior intentions in Pakistan, a South Asian country facing severe energy

Table 1: Results for the measurement model

\begin{tabular}{|c|c|c|c|c|c|c|}
\hline Variable & Abbreviation & Measurement items & Estimate & $\mathrm{CR}$ & AVE & Alpha \\
\hline \multirow[t]{3}{*}{ Awareness } & \multirow[t]{3}{*}{ AWR } & AWR1 & .749 & \multirow[t]{3}{*}{.79} & \multirow[t]{3}{*}{.55} & \multirow[t]{3}{*}{.78} \\
\hline & & AWR2 & .832 & & & \\
\hline & & AWR3 & .646 & & & \\
\hline \multirow[t]{3}{*}{ Compatibility } & \multirow[t]{3}{*}{$\mathrm{COM}$} & COM1 & .731 & \multirow[t]{3}{*}{.85} & \multirow[t]{3}{*}{.65} & \multirow[t]{3}{*}{.84} \\
\hline & & COM2 & .850 & & & \\
\hline & & COM3 & .845 & & & \\
\hline \multirow[t]{3}{*}{ Perceived value } & \multirow[t]{3}{*}{ PCV } & PCV1 & .689 & \multirow[t]{3}{*}{.77} & \multirow[t]{3}{*}{.53} & \multirow[t]{3}{*}{.759} \\
\hline & & PCV2 & .894 & & & \\
\hline & & PCV3 & .579 & & & \\
\hline \multirow{4}{*}{$\begin{array}{l}\text { Resistance to } \\
\text { change }\end{array}$} & \multirow[t]{4}{*}{ RES } & RES1 & .555 & \multirow[t]{4}{*}{.85} & \multirow[t]{4}{*}{.53} & \multirow[t]{4}{*}{.750} \\
\hline & & RES2 & .671 & & & \\
\hline & & RES3 & .919 & & & \\
\hline & & RES4 & .772 & & & \\
\hline
\end{tabular}




\begin{tabular}{|c|c|c|c|c|c|c|}
\hline \multirow[t]{3}{*}{ Actual gain } & \multirow[t]{3}{*}{ ACG } & ACG1 & .698 & \multirow[t]{3}{*}{.78} & \multirow[t]{3}{*}{.54} & \multirow[t]{3}{*}{.712} \\
\hline & & ACG2 & .789 & & & \\
\hline & & ACG3 & .735 & & & \\
\hline \multirow{4}{*}{$\begin{array}{l}\text { Attitude towards } \\
\text { energy conser- } \\
\text { vation }\end{array}$} & \multirow[t]{4}{*}{ ATT } & ATT1 & .713 & \multirow[t]{4}{*}{.84} & \multirow[t]{4}{*}{.50} & \multirow[t]{4}{*}{.791} \\
\hline & & ATT2 & .713 & & & \\
\hline & & ATT3 & .704 & & & \\
\hline & & ATT4 & .709 & & & \\
\hline \multirow{4}{*}{$\begin{array}{c}\text { Sustainable } \\
\text { behavioral inten- } \\
\text { tions }\end{array}$} & \multirow[t]{4}{*}{ BINT } & BINT1 & .797 & \multirow[t]{4}{*}{.88} & \multirow[t]{4}{*}{.66} & \multirow[t]{4}{*}{.871} \\
\hline & & BINT2 & .824 & & & \\
\hline & & BINT3 & .801 & & & \\
\hline & & BINT4 & .833 & & & \\
\hline
\end{tabular}

Note1. $\mathrm{CMIN} / \mathrm{df}=1.965, \mathrm{p} \leq 0.00, \mathrm{GFI}=.898, \mathrm{AGFI}=.872, \mathrm{NFI}=.861, \mathrm{CFI}=.925, \mathrm{RMSEA}=0.051$.

Note2: $\mathrm{CR}=$ Composite Relability, $\mathrm{AVE}=$ Aeverage variance extracted, Alpha= Cronbach's alpha

Table 2: Fornell-Larcker Discriminant Validity and Correlation Analysis

\begin{tabular}{|c|c|c|c|c|c|c|c|c|c|c|}
\hline $\begin{array}{c}\text { Con- } \\
\text { structs }\end{array}$ & Means & SD & SQRT & & & & & & & \\
\hline AVE & AWR & COM & PCV & RES & ACG & ATT & BINT & & & \\
\hline AWR & 3.21 & .280 & .741 & $(.74)$ & & & & & & \\
\hline COM & 3.32 & .432 & .806 & $.58^{* *}$ & $(.80)$ & & & & & \\
\hline PCV & 3.19 & .219 & .728 & $-.29^{* *}$ & $-.22^{* *}$ & $(.72)$ & & & & \\
\hline RES & 2.67 & .323 & .734 & $-.69^{* *}$ & $.15^{* *}$ & $.18^{*}$ & $(.73)$ & & & \\
\hline ACG & 3.36 & .496 & .728 & $.47^{* *}$ & $-.37^{* *}$ & $.46^{* *}$ & $.42^{* *}$ & $(.72)$ & & \\
\hline ATT & 3.72 & .504 & .707 & $.40^{* *}$ & $.18^{* *}$ & $.58^{* *}$ & $-.34^{* *}$ & $.26^{* *}$ & $(.70)$ & \\
\hline BI & 3.01 & .398 & .806 & $.29^{* *}$ & $.68^{* *}$ & $.41^{* *}$ & $-.38^{* *}$ & $.27^{* *}$ & $.74^{* *}$ & $(.80)$ \\
\hline
\end{tabular}

Note: $\mathrm{n}=246,{ }^{* *}$ Significant at $\mathrm{p}<.01$ level; ${ }^{*}$ Significant at $\mathrm{p}<0.05$ level

Table 3: Results for structural model

\begin{tabular}{|c|c|c|c|c|}
\hline & Estimate & S.E. & C.R. & P \\
\hline ATT $\leftarrow$ AWR & .134 & .022 & 6.032 & $* * *$ \\
\hline ATT $\leftarrow$ COM & .092 & .022 & 4.238 & $* * *$ \\
\hline ATT $\leftarrow$ PCV & .141 & .030 & 4.743 & $* * *$ \\
\hline ATT $\leftarrow$ RES & .235 & .030 & -7.789 & $* * *$ \\
\hline ATT $\leftarrow$ ACG & .136 & .022 & 6.140 & $* * *$ \\
\hline BINT $\leftarrow$ AWR & .100 & .017 & 5.815 & $* * *$ \\
\hline
\end{tabular}




\begin{tabular}{|c|c|c|c|c|}
\hline BINT $\leftarrow$ COM & .065 & .017 & 3.914 & $* * *$ \\
\hline BINT $\leftarrow$ PCV & .022 & .023 & .957 & .339 \\
\hline BINT $\leftarrow$ RES & .212 & .023 & -9.105 & $* * *$ \\
\hline BINT $\leftarrow$ ACG & .116 & .017 & 6.786 & $* * *$ \\
\hline BINT $\leftarrow$ ATT & .505 & .067 & 12.049 & $* * *$ \\
\hline
\end{tabular}

Note1. $\mathrm{CMIN} / \mathrm{df}=1.707, \mathrm{GFI}=.909, \mathrm{AGFI}=.891, \mathrm{NFI}=.880, \mathrm{CFI}=.946, \mathrm{RMSEA}=0.044$

Note2. ${ }^{* *}$ Significant at $\mathrm{p}<.01$ level; ${ }^{*}$ Significant at $\mathrm{p}<0.05$ level

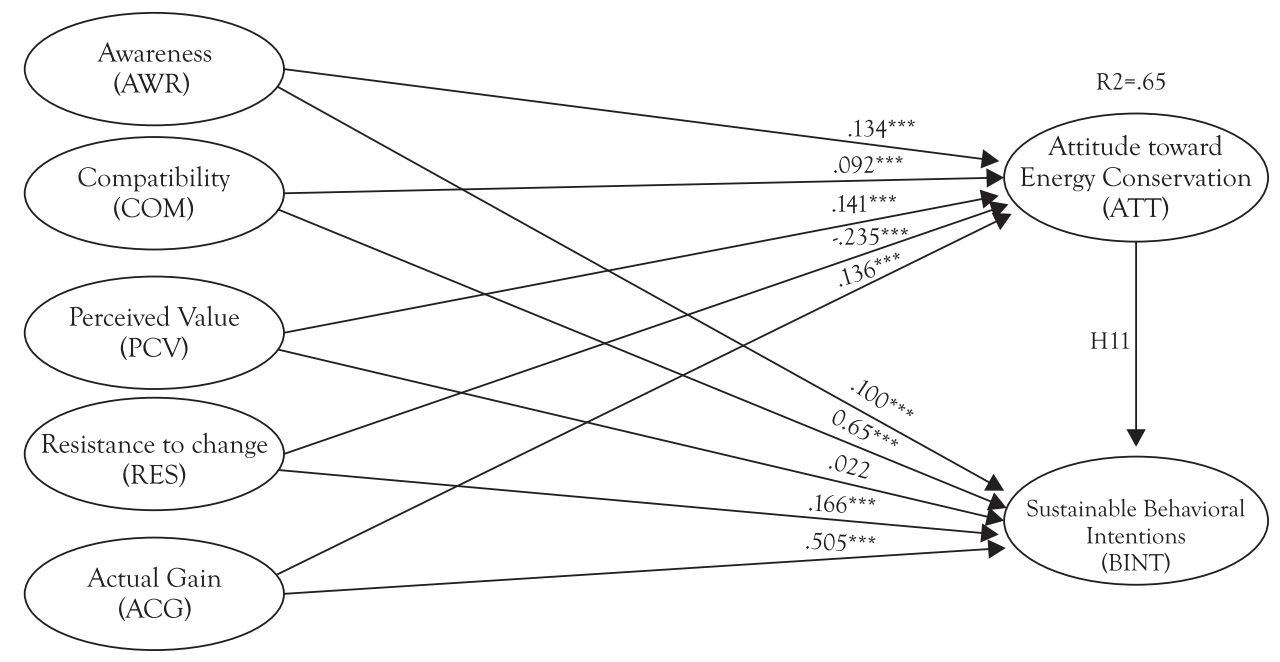

Figure 2: Results of the Structural Model

crisis. The study specified that the attitude towards electricity conservation is a key precursor of sustainable behavioral intentions and validates the theory of planned behavior (Ajzen, 2001). These results are consistent with the existing literature, which indicates a strong linkage between attitude and behavioral intentions (Rahbar \& Abdul Wahid, 2011; Ramayah \& Rahbar, 2013; Zhao, Gao, Wu, Wang \& Zhu, 2014). It implies that customer with a positive attitude towards energy conservation holds favorable intentions towards energy conservation.

The results demonstrated that amount of actual gain and awareness are the main contributors to attitude and behavioral intention. The results are consistent with past empirical findings (Bredahl, 2001; Hamstra \& Smink, 1996; Sparks \& Shepherd, 1994). For example, awareness about the wastage of resources and scarcity of natural resources for future generations caused by excessive electricity use also drive consumers to conserve electricity. The favorable perceptions about the benefits gain such extended life span of natural resources, economic and social benefits increase the likelihood of conservation of electricity. The consumer with a higher level of knowledge is more 
adaptive towards innovative techniques to replace conventional electricity usage. In a nutshell, consumers get motivated to conserve electricity through the perceptions of benefits gain due to energy conservation and awareness about the possible harmful effects of electricity waste.

The findings also illustrate that resistance to change and compatibility are related to the attitude towards energy conservation and behavioral intentions significantly. These results are also in line with the existing literature (Oreg, 2006; Ramayah \& Rahbar, 2013; Rogers, 2002; Saksvik \& Hetland, 2009; Sidique, Lupi \& Joshi, 2010). It may be noticed that consumers may feel the hassle of changing their electricity usage practices and find out more about the benefits of installing electricity conserving practices. Consumers feel that their cost of electricity conserving practices may not drop significantly compared to benefits sacrificed in conserving practices and remain stick to their conventional practices of electricity consumption. The establishment of structural relationships of beliefs and values towards energy conservation (awareness, compatibility, actual gain, and resistance to change) suggest that beliefs and values are translated into attitude, which then dictates their sustainable behavioral intentions. Surprisingly, findings related to perceived value depicted a significant impact on attitude towards energy conservation while an insignificant impact on sustainable behavioral intentions, which is inconsistent with most of the existing literature; however, Homer and Kahle (1988) found an insignificant relationship between perceived value and behavioral intentions. The findings suggest that Pakistani electricity consumers do not consider that their electricity conservation will minimize the energy crisis.

\subsection{Implications}

This study presents an in-depth investigation of consumer intention towards energy conservation. It provides valuable insight to academicians, marketers, and policymakers by identifying and examining the important variables that impact Pakistani consumers' electricity consumption practices and behaviors.

\subsubsection{Theoretical implications}

This research extends the stream of research regarding the drivers of sustainable behavioral intentions. The current study contributes to theoretical advancement in modeling consumer behavior intentions in electricity conservation of developing countries such as Pakistan by utilizing the theoretical grounds of the theory of planned behavior. This study adds to scholarly knowledge by testing awareness, compatibility, perceived value, resistance to change, and actual gain as predictors of attitude towards energy conservation and sustainable behavioral intentions. 


\subsubsection{Practical Implications}

From the managerial perspective, the study results suggest that the marketing manager should have a deep concern regarding a positive attitude to develop favorable intentions of consumers towards an energy-efficient product or brand. The research outcome indicates that beliefs and values are key contributors of attitude toward energy conservation which results in positive sustainability behavioral intentions. Therefore, marketers should use a factual and convincing approach to depict energy conservation practices as energy and cost-saving. Results of the study illustrate that awareness and actual gain are important precursors that translate into attitude. Figures related to the monetary amount indicate that one can save by adopting energy-efficient practices, which may be highlighted to construct a sound reason. Although Pakistan Electric Power Company (Pepco) uses a comparative approach to realize electricity consumers, they can get monetary benefits by saving power. To increase awareness, seminars and campaigns for urban and rural levels can therefore be designed. A pronounced finding of this study is a negative relation between attitude and aversion to change towards energy-efficient practices. The results exhibit that people feel reluctant to change their practices. Marketers have to utilize informational advertisements for the awareness of the electricity consumer.

\subsection{Future research and limitations}

There are some notable limitations in terms of the generalizability and interpretation of the results. First, research findings are based on a cross-sectional sample, which can be argued to make causal inferences. For instance, it may be possible that normative influence and attitude towards energy conservation may not immediately transform into sustainable behavioral intentions. Future research considering longitudinal research design may provide better insight into the relational paths and allow causal inferences. The second study sample was recruited only from Pakistan. The generalisability of the study findings to other cultures and countries is unwarranted. Future research may consider different cultural groups to develop a comprehensive understanding of energy conservation intentions. Third, the main emphasis of the study was on behavioral intentions, which is assessed by self-reported answers, which may be subject to social desirability bias. Further exploration may be needed for better comprehension by using other research approaches for more accurate results. In addition to this, we recommend to replicated this research model for different sustainable consumption behaviors like recycling, green consumption intentions (organic buying), which may provide different results. 


\section{References}

Abbasi, K. R., Abbas, J., Mahmood, S., \& Tufail, M. (2021). Revisiting electricity consumption, price, and real GDP: A modified sectoral level analysis from Pakistan. Energy Policy, 149 February, 112087. https://doi.org/10.1016/j.enpol.2020.112087

Ahmad, A., Kashif, S. A. R., Saqib, M. A., Ashraf, A., \& Shami, U. T. (2019). Tariff for reactive energy consumption in household appliances. Energy, 186 (November), 115818. https://doi.org/10.1016/j. energy.2019.07.148

Ahmad, M. I., \& Riffat, S. (2020). Introduction: Energy, Green Innovation and Sustainable Future. In Energy Recovery Technology for Building Applications (pp. 1-4). Springer. Cham. https://doi. org/10.1007/978-3-030-50006-1_1

Ajzen, I. (2001). Nature and Operation of Attitudes. Annual Review of Psychology, 52(1), 27-58. https:// doi.org/10.1146/annurev.psych.52.1.27

Arora, N. K., \& Mishra, I. (2019). United Nations Sustainable Development Goals 2030 and environmental sustainability: race against time. Environmental Sustainability, 2 (November), 339-342. https://doi.org/10.1007/s42398-019-00092-y

Bamberg, S., \& Möser, G. (2007). Twenty years after Hines, Hungerford, and Tomera: A new meta-analysis of psycho-social determinants of pro-environmental behaviour. Journal of Environmental Psychology, 27(1), 14-25.

Biresselioglu, M. E., Demir, M. H., Rashid, A., Solak, B., \& Ozyorulmaz, E. (2019). What are the preferences of household energy use in Pakistan?: Findings from a national survey. Energy and Buildings, 205 (December), 109538. https://doi.org/10.1016/j.enbuild.2019.109538

Bonnes, M., \& Bonaiuto, M. (2002). Environmental psychology: From spatial-physical environment to sustainable development. In R. B. Bechtel \& A. Churchman (Eds.), Handbook of environmental psychology (p. 28-54). John Wiley \& Sons, Inc. Washington, DC

Bredahl, L. (2001). Determinants of consumer attitudes and purchase intentions with regard to genetically modified food-results of a cross-national survey. Journal of Consumer Policy, 24(1), 23-61.

Bruderer Enzler, H., Diekmann, A., \& Liebe, U. (2019). Do environmental concern and future orientation predict metered household electricity use? Journal of Environmental Psychology, 62 (April), 22-29. https://doi.org/10.1016/j.jenvp.2019.02.004

Campbell, J. Y. (2006). Household finance. The Journal of Finance, 61(4), 1553-1604.

Chandio, A. A., Rauf, A., Jiang, Y., Ozturk, I., \& Ahmad, F. (2019). Cointegration and causality analysis of dynamic linkage between industrial energy consumption and economic growth in Pakistan. Sustainability, 11(17), 4546. https://doi.org/10.3390/su11174546

Chen, L., Gillenson, M. L., \& Sherrell, D. L. (2002). Enticing online consumers: An extended technol- 
ogy acceptance perspective. Information $\mathcal{E}$ Management, 39(8), 705-719. https://doi.org/10.1016/ S0378-7206(01)00127-6

Chen, M.-F. (2016). Extending the theory of planned behavior model to explain people's energy savings and carbon reduction behavioral intentions to mitigate climate change in Taiwan-moral obligation matters. Journal of Cleaner Production, 112 (2), 1746-1753.

Chen, S.-C., \& Hung, C.-W. (2016). Elucidating the factors influencing the acceptance of green products: An extension of theory of planned behavior. Technological Forecasting and Social Change, 112 (November), 155-163. https://doi.org/10.1016/j.techfore.2016.08.022

Chiu, M.-C., Kuo, T.-C., \& Liao, H.-T. (2020). Design for sustainable behavior strategies: Impact of persuasive technology on energy usage. Journal of Cleaner Production, 248 (1), 119214.

Corral-Verdugo, V., Mireles-Acosta, J. F., Tapia-Fonllem, C., \& Fraijo-Sing, B. (2011). Happiness as correlate of sustainable behavior: A study of pro-ecological, frugal, equitable and altruistic actions that promote subjective wellbeing. Human Ecology Review, 18 (2), 95-104.

Degirmenci, K., \& Breitner, M. H. (2017). Consumer purchase intentions for electric vehicles: Is green more important than price and range? Transportation Research Part D: Transport and Environment, 51 (March), 250-260. https://doi.org/10.1016/j.trd.2017.01.001

Fabi, V., Di Nicoli, M. V., Spigliantini, G., \& Corgnati, S. P. (2017). Insights on pro-environmental behavior towards post-carbon society. Energy Procedia (October), 134, 462-469. https://doi. org/10.1016/j.egypro.2017.09.604

Fornara, F., Pattitoni, P., Mura, M., \& Strazzera, E. (2016). Predicting intention to improve household energy efficiency: The role of value-belief-norm theory, normative and informational influence, and specific attitude. Journal of Environmental Psychology (March), 45, 1-10. https://doi.org/10.1016/j. jenvp.2015.11.001

Fornell, C., \& Larcker, D. F. (1981). Evaluating structural equation models with unobservable variables and measurement error. Journal of Marketing Research, 18(1), 39-50.

Gaustad, T., Samuelsen, B. M., Warlop, L., \& Fitzsimons, G. J. (2019). Too much of a good thing? Consumer response to strategic changes in brand image. International Journal of Research in Marketing, 36(2), 264-280.

Gkargkavouzi, A., Halkos, G., \& Matsiori, S. (2019). Environmental behavior in a private-sphere context: Integrating theories of planned behavior and value belief norm, self-identity and habit. Resources, Conservation and Recycling, 148 (September), 145-156. https://doi.org/10.1016/j.resconrec.2019.01.039

Ha, H.Y., \& Janda, S. (2012). Predicting consumer intentions to purchase energy-efficient products. Journal of Consumer Marketing, 29 (7), 461-469.

Hair, J. F., Sarstedt, M., Ringle, C. M., \& Mena, J. A. (2012). An assessment of the use of partial least squares structural equation modeling in marketing research. Journal of the Academy of Marketing 
Science, 40(3), 414-433. https://doi.org/10.1007/s11747-011-0261-6

Hamstra, A. M., \& Smink, C. (1996). Consumers and biotechnology in the Netherlands. British Food Journal, 98(4/5), 34-38.

Hantrais, L., Kattumuri, R., \& Lenihan, A. T. (2020). Sustaining Natural Resources in a Changing Environment. Routledge. London, United Kingdom.

Heo, J., \& Muralidharan, S. (2019). What triggers young Millennials to purchase eco-friendly products?: The interrelationships among knowledge, perceived consumer effectiveness, and environmental concern. Journal of Marketing Communications, 25(4), 421-437.

Homer, P. M., \& Kahle, L. R. (1988). A structural equation test of the value-attitude-behavior hierarchy. Journal of Personality and Social Psychology, 54(4), 638-646.

Islam, M. T., Dias, P., \& Huda, N. (2021). Young consumers' e-waste awareness, consumption, disposal, and recycling behavior: A case study of university students in Sydney, Australia. Journal of Cleaner Production, 282 (1), 124490. https://doi.org/10.1016/j.jclepro.2020.124490

Jannoo, Z., Yap, B. W., Auchoybur, N., \& Lazim, M. A. (2014). The effect of nonnormality on CB-SEM and PLS-SEM path estimates. International Journal of Mathematical, Computational, Physical and Quantum Engineering, 8(2), 285-291.

Kaiser, F. G., Kibbe, A., \& Arnold, O. (2017). Self-Determined, Enduring, Ecologically Sustainable Ways of Life: Attitude as a Measure of Individuals' Intrinsic Motivation. In G. Fleury-Bahi, E. Pol, \& O. Navarro (Eds.), Handbook of Environmental Psychology and Quality of Life Research (pp. 185-195). Cham. Springer International Publishing. https://doi.org/10.1007/978-3-319-31416-7_10

Kautish, P., Khare, A., \& Sharma, R. (2020). Influence of values, brand consciousness and behavioral intentions in predicting luxury fashion consumption. Journal of Product $\mathcal{E}$ Brand Management, 30(4), 513-531. https://doi.org/10.1108/JPBM-08-2019-2535

Khan, F., Ahmed, W., \& Najmi, A. (2019). Understanding consumers' behavior intentions towards dealing with the plastic waste: Perspective of a developing country. Resources, Conservation and Recycling, 142 (March), 49-58.

Khan, I. (2019). Energy-saving behaviour as a demand-side management strategy in the developing world: The case of Bangladesh. International Journal of Energy and Environmental Engineering, 10 (4), 493-510.

Knussen, C., Yule, F., MacKenzie, J., \& Wells, M. (2004). An analysis of intentions to recycle household waste: The roles of past behaviour, perceived habit, and perceived lack of facilities. Journal of Environmental Psychology, 24(2), 237-246. https://doi.org/10.1016/j.jenvp.2003.12.001

Konuk, F. A. (2019). The influence of perceived food quality, price fairness, perceived value and satisfaction on customers' revisit and word-of-mouth intentions towards organic food restaurants. Journal of Retailing and Consumer Services, 50 (September), 103-110. https://doi.org/10.1016/j. jretconser.2019.05.005 
Kornilaki, M., \& Font, X. (2019). Normative influences: How socio-cultural and industrial norms influence the adoption of sustainability practices. A grounded theory of Cretan, small tourism firms. Journal of Environmental Management, 230 (Janurary), 183-189.

Latif, K., Raza, M. Y., Chaudhary, G. M., \& Arshad, A. (2020). Analysis of Energy Crisis, Energy Security and Potential of Renewable Energy: Evidence from Pakistan. Journal of Accounting and Finance in Emerging Economies, 6(1), 167-182.

Liobikienè, G., \& Poškus, M. S. (2019). The importance of environmental knowledge for private and public sphere pro-environmental behavior: Modifying the value-belief-norm theory. Sustainability, 11(12), 3324.

Lopes, J. R. N., Kalid, R. de A., Rodríguez, J. L. M., \& Ávila Filho, S. (2019). A new model for assessing industrial worker behavior regarding energy saving considering the theory of planned behavior, norm activation model and human reliability. Resources, Conservation and Recycling, 145 (June), 268-278. https://doi.org/10.1016/j.resconrec.2019.02.042

Lovelock, C., Patterson, P., \& Wirtz, J. (2014). Services Marketing, 6th Editio. Australia: Pearson Australia.

Lunden, S., Sundström, L., \& Suliman, A. (2020). The effect of marketing appeals on consumers' intention to pro-environmental behaviour: A social marketing study applying the Theory of planned behaviour in Jönköping, Sweden. Retrieved from http://urn.kb.se/resolve?urn=urn:nbn:se:hj:diva-49006

Mahardika, H., Thomas, D., Ewing, M. T., \& Japutra, A. (2020). Comparing the temporal stability of behavioural expectation and behavioural intention in the prediction of consumers pro-environmental behaviour. Journal of Retailing and Consumer Services, 54 (May), 101943. https://doi.org/10.1016/j. jretconser.2019.101943

Malodia, S., \& Bhatt, A. S. (2019). Why Should I Switch Off: Understanding the Barriers to Sustainable Consumption? Vision, 23 (2), 134-143.

Mangi, M. Y., Yue, Z., Kalwar, S., \& Ali Lashari, Z. (2020). Comparative Analysis of Urban Development Trends of Beijing and Karachi Metropolitan Areas. Sustainability, 12 (2), 451.

Mayer, F. S., \& Frantz, C. M. (2004). The connectedness to nature scale: A measure of individuals' feeling in community with nature. Journal of Environmental Psychology, 24 (4), 503-515. https://doi. org/10.1016/j.jenvp.2004.10.001

Meuter, M. L., Bitner, M. J., Ostrom, A. L., \& Brown, S. W. (2005). Choosing among alternative service delivery modes: An investigation of customer trial of self-service technologies. Journal of Marketing, 69 (2), 61-83.

Mróz, A., Ocetkiewicz, I., \& Tomaszewska, B. (2020). What should be included in education programmes-The socio-education analysis for sustainable management of natural resources. Journal of Cleaner Production, 250 (March), 119556.

Nguyen, T. N., Lobo, A., \& Greenland, S. (2017). Energy efficient household appliances in emerging 
markets: The influence of consumers' values and knowledge on their attitudes and purchase behaviour. International Journal of Consumer Studies, 41(2), 167-177.

Nie, H., Vasseur, V., Fan, Y., \& Xu, J. (2019). Exploring reasons behind careful-use, energy-saving behaviours in residential sector based on the theory of planned behaviour: Evidence from Changchun, China. Journal of Cleaner Production, 230 (September), 29-37. https://doi.org/10.1016/j. jclepro.2019.05.101

Ohtomo, S., \& Hirose, Y. (2007). The dual-process of reactive and intentional decision-making involved in eco-friendly behavior. Journal of Environmental Psychology, 27(2), 117-125.

O'Leary-Kelly, S. W., \& J. Vokurka, R. (1998). The empirical assessment of construct validity. Journal of Operations Management, 16(4), 387-405. https://doi.org/10.1016/S0272-6963(98)00020-5

Oreg, S. (2006). Personality, context, and resistance to organizational change. European Journal of Work and Organizational Psychology, 15(1), 73-101.

Pakistan Bureau of Statistics. (2018). Retrieved 17 May 2018, from http://www.pbs.gov.pk/

Panda, T. K., Kumar, A., Jakhar, S., Luthra, S., Garza-Reyes, J. A., Kazancoglu, I., \& Nayak, S. S. (2020). Social and environmental sustainability model on consumers' altruism, green purchase intention, green brand loyalty and evangelism. Journal of Cleaner Production, 243(January), 118575. https:// doi.org/10.1016/j.jclepro.2019.118575

Parasuraman, A., Zeithaml, V. A., \& Berry, L. L. (1985). A conceptual model of service quality and its implications for future research. Journal of Marketing, 49(4), 41-50.

Park, E., \& Kwon, S. J. (2017). What motivations drive sustainable energy-saving behavior?: An examination in South Korea. Renewable and Sustainable Energy Reviews, 79 (November), 494-502. https:// doi.org/10.1016/j.rser.2017.05.150

Quoquab, F., Mohammad, J., \& Sukari, N. N. (2019). A multiple-item scale for measuring "sustainable consumption behaviour" construct: Development and psychometric evaluation. Asia Pacific Journal of Marketing and Logistics, 31(4), 791-816. https://doi.org/10.1108/APJML-02-2018-0047

Rahbar, E., \& Abdul Wahid, N. (2011). Investigation of green marketing tools' effect on consumers' purchase behavior. Business Strategy Series, 12(2), 73-83. https://doi.org/10.1108/17515631111114877

Rahman, M., Aziz, S., \& Hughes, M. (2020). The product-market performance benefits of environmental policy: Why customer awareness and firm innovativeness matter. Business Strategy and the Environment. 29 (Feburary), 2001- 2018. https://doi.org/10.1002/bse.2484

Ramayah, T., \& Rahbar, E. (2013). Greening the environment through recycling: An empirical study. Management of Environmental Quality: An International Journal, 24(6), 782-801. https://doi. org/10.1108/MEQ-07-2012-0054

Rehman, M. (2018, September 3). Pakistan's electricity generation has increased over time. So why do 
we still not have uninterrupted supply? Retrieved 14 August 2020, from DAWN.COM website: https://www.dawn.com/news/1430728

Ren, G., Sunikka-Blank, M., \& Zhang, X. (2020). Young urban households in Shanghai, China: Characteristics of energy use and attitudes. Sustainable Cities and Society, 60 (September), 102174. https:// doi.org/10.1016/j.scs.2020.102174

Rex, J., Lobo, A., \& Leckie, C. (2015). Evaluating the drivers of sustainable behavioral intentions: An application and extension of the theory of planned behavior. Journal of Nonprofit $\mathcal{E}$ Public Sector Marketing, 27(3), 263-284.

Rezvani, Z., Jansson, J., \& Bengtsson, M. (2018). Consumer motivations for sustainable consumption: The interaction of gain, normative and hedonic motivations on electric vehicle adoption. Business Strategy and the Environment, 27(8), 1272-1283.

Rogers, E. M. (2002). Diffusion of preventive innovations. Addictive Behaviors, 27(6), 989-993.

Roos, D., \& Hahn, R. (2019). Understanding collaborative consumption: An extension of the theory of planned behavior with value-based personal norms. Journal of Business Ethics, 158(3), 679-697.

Ryu, K., Lee, H.-R., \& Gon Kim, W. (2012). The influence of the quality of the physical environment, food, and service on restaurant image, customer perceived value, customer satisfaction, and behavioral intentions. International Journal of Contemporary Hospitality Management, 24(2), 200-223.

Saksvik, I. B., \& Hetland, H. (2009). Exploring dispositional resistance to change. Journal of Leadership $\mathcal{E}$ Organizational Studies. Retrieved from http://jlo.sagepub.com/content/early/2009/04/21/1548051809335357.short

Savari, M., \& Gharechaee, H. (2020). Application of the extended theory of planned behavior to predict Iranian farmers' intention for safe use of chemical fertilizers. Journal of Cleaner Production, 263 (August), 121512. https://doi.org/10.1016/j.jclepro.2020.121512

Schwartz, S. H. (1977). Normative influences on altruism. Advances in Experimental Social Psychology, 10(1), 221-279.

Shah, S. A. A., \& Solangi, Y. A. (2019). A sustainable solution for electricity crisis in Pakistan: Opportunities, barriers, and policy implications for 100\% renewable energy. Environmental Science and Pollution Research, 26(29), 29687-29703. https://doi.org/10.1007/s11356-019-06102-0

Shi, D., Wang, L., \& Wang, Z. (2019). What affects individual energy conservation behavior: Personal habits, external conditions or values? An empirical study based on a survey of college students. Energy Policy, 128 (May), 150-161.

Sidique, S. F., Lupi, F., \& Joshi, S. V. (2010). The effects of behavior and attitudes on drop-off recycling activities. Resources, Conservation and Recycling, 54(3), 163-170.

Sonetti, G., Brown, M., \& Naboni, E. (2019). About the triggering of UN sustainable development 
goals and regenerative sustainability in higher education. Sustainability, 11(1), 254. https://doi. org/10.3390/su11010254

Sparks, P., \& Shepherd, R. (1994). Public perceptions of the potential hazards associated with food production and food consumption: An empirical study. Risk Analysis, 14(5), 799-806.

Sun, W., Zhang, X., Li, H., Wu, J., \& Zheng, S. (2018). Environmental ideology and household energy conservation in Beijing. Journal of Cleaner Production, 195 (September), 1600-1608. https://doi. org/10.1016/j.jclepro.2017.07.065

Tan, C.-S., Ooi, H.Y., \& Goh, Y.-N. (2017). A moral extension of the theory of planned behavior to predict consumers' purchase intention for energy-efficient household appliances in Malaysia. Energy Policy, 107 (August), 459-471. https://doi.org/10.1016/j.enpol.2017.05.027

Thøgersen, J. (2021). Consumer behavior and climate change: Consumers need considerable assistance. Current Opinion in Behavioral Sciences, 42 (December), 9-14. https://doi.org/10.1016/j. cobeha.2021.02.008

Trotta, G. (2021). Electricity awareness and consumer demand for information. International Journal of Consumer Studies, 45(1), 65-79. https://doi.org/10.1111/ijcs.12603

Tzeng, J.-Y. (2011). Perceived values and prospective users' acceptance of prospective technology: The case of a career eportfolio system. Computers $\mathcal{E}$ Education, 56(1), 157-165.

van den Broek, K. L., Walker, I., \& Klöckner, C. A. (2019). Drivers of energy saving behaviour: The relative influence of intentional, normative, situational and habitual processes. Energy Policy (September), 132, 811-819. https://doi.org/10.1016/j.enpol.2019.06.048

Vess, M. (2019). Varieties of conscious experience and the subjective awareness of one's "true" self. Review of General Psychology, 23(1), 89-98.

Wang, B., Wang, X., Guo, D., Zhang, B., \& Wang, Z. (2018). Analysis of factors influencing residents' habitual energy-saving behaviour based on NAM and TPB models: Egoism or altruism? Energy Policy, 116 (May), 68-77. https://doi.org/10.1016/j.enpol.2018.01.055

Waris, I., \& Ahmed, W. (2020). Empirical evaluation of the antecedents of energy-efficient home appliances: Application of extended theory of planned behavior. Management of Environmental Quality. 31(4), 915-930. https://doi.org/10.1108/MEQ-01-2020-0001

Weissmann, M. A. (2020). A Behavioural Control Investigation Towards Greater Sustainability (PhD Thesis). Swinburne University of Technology. Reterived from https://researchbank.swinburne.edu.au/ items/99d5efe9-1c33-4863-9ba0 f4c28d44eed2/1/marc_weissmann_thesis.pdf?.vi=save

Wolf, E. J., Harrington, K. M., Clark, S. L., \& Miller, M. W. (2013). Sample size requirements for structural equation models: An evaluation of power, bias, and solution propriety. Educational and Psychological Measurement, 73(6), 913-934. 
Wynter-Hoyte, K., Braden, E. G., Rodriguez, S., \& Thornton, N. (2019). Disrupting the status quo: Exploring culturally relevant and sustaining pedagogies for young diverse learners. Race Ethnicity and Education, 22(3), 428-447.

Yin J., Tao H., Jiang X. (2020) Investigation on the Value Judgment Criteria of Customized Garment Products by Mass Consumers. In: Kantola J., Nazir S. (eds) Advances in Human Factors, Business Management and Leadership. AHFE 2019. Advances in Intelligent Systems and Computing, vol 961. Springer, Cham. https://doi.org/10.1007/978-3-030-20154-8_29

Yuriev, A., Dahmen, M., Paillé, P., Boiral, O., \& Guillaumie, L. (2020). Pro-environmental behaviors through the lens of the theory of planned behavior: A scoping review. Resources, Conservation and Recycling, 155 (April), 104660. https://doi.org/10.1016/j.resconrec.2019.104660

Zehra, F., \& Siddiqui, D. A. (2019). Organizational Change and Employees' Psychological Well-Being: The Mediatory Role of Resistance to Change. Available at SSRN 3510555.

Zhao, Hui-hui, Gao, Q., Wu, Y., Wang, Y., \& Zhu, X. (2014). What affects green consumer behavior in China? A case study from Qingdao. Journal of Cleaner Production, 63, 143-151. https://doi. org/10.1016/j.jclepro.2013.05.021 
